Mateusz NOWAK

\title{
Modern drive systems of rail vehicles
}

Rail vehicles are one of the sources of environmental pollution in the transport sector. Therefore, it is necessary to equip these vehicles with modern drive systems. This article concerns the issues of contemporary and future-oriented solutions of drive systems used in rail vehicles. The article analyzes energy storage possibilities including: electrochemical, mechanical and hydraulic accumulators. The conducted analyzes have taken into account the importance of how frequently they charge up, which dictates their possible applications. Characteristics of hybrid drive systems were presented, with particular emphasis on parallel systems of: hydrostatic, flywheels and electrochemical batteries. The analysis of energy flow control strategies in hybrid drive systems of railway vehicles has been made. In the summary, a solution was chosen that resulted in high conversion efficiency of the energy extracted from the vehicle's wheels.

Keywords: rail vehicles, combustion engines, hybrid drive systems

\section{Introduction}

In recent years, the share of $\mathrm{CO}_{2}$ emissions from the transport sector has been steadily increasing (Fig. 1). This share of $\mathrm{CO}_{2}$ emissions has increased from $22.7 \%$ in 2010 to $23.4 \%$ in 2013 [24]. In 2013, carbon dioxide emissions from rail transport reached $3.5 \%$, while it accounted for $8 \%$ of the world's passenger and freight volume. The railway sector in 2013 also accounted for just $2 \%$ of the total energy consumed in the transport sector. Rail vehicles were fueled with petroleum products in $57 \%$ of cases, and in $36.4 \%$ of cases with electricity.

In 2013, six regions and countries (EU28, USA, Russia, China, India, Japan) accounted for $78 \%$ of total $\mathrm{CO}_{2}$ emissions in the rail sector, of which one quarter were emitted by China.

Coal consumption by the rail sector drastically decreased in 1990-2013. In the same period, electricity consumption in rail transport increased from $17.2 \%$ to $36.4 \%$.

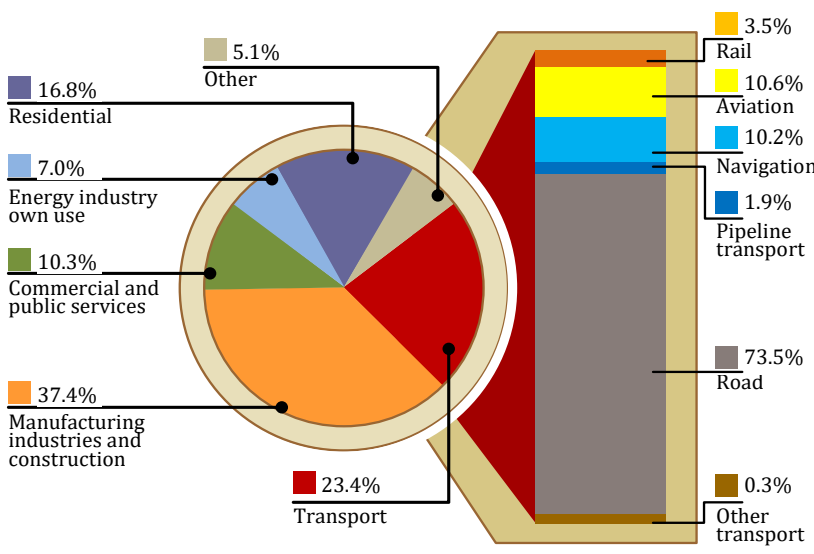

Fig. 1. Carbon dioxide emission as a result of fossil fuel combustion in various industry and transport sectors [24]

The share of electrified railway lines increased by $163 \%$ in the span between 1975-2013 at the global level. China and Korea increased their share by $325 \%$ and $343 \%$ respectively between 1990-2013.
In 2013, the specific energy consumption in passenger rail transport reached $138 \mathrm{~kJ} / \mathrm{km}$, whereas this volume in rail freight transport amounted to $129 \mathrm{~kJ} / \mathrm{km}$. The energy consumption in this transport sector in the years 1975-2013 decreased by $63 \%$ and $48 \%$ respectively for passenger and freight transport. Individual emissions of carbon dioxide in the railway sector show a similar improvement rate: they were reduced by $60 \%$ in passenger transport and by $38 \%$ in freight transport in the years 1975-2013.

\section{Energy storage systems in rail transport vehicles}

The constant pursuit of reducing emissions from transport means has lead to restrictions also being applied to rail vehicles. The introduction of subsequent exhaust emission limits in relation to rail traction vehicles means that the currently applicable EU legal acts include Stage III $\mathrm{B}$ and Stage V limits. The latter limit is in force for new vehicle approvals from this year onwards [7, 20]. Despite the trend where the share of drives relying on combustion engines in the total number of rail vehicles continues to decrease, there is a tendency to replace the conventional combustion systems with hybrid systems $[5,15]$. Meinert et al. [16] proposed the use of energy storage systems (ESS) in rail vehicles, such as: hydrostatic systems, batteries, flywheels and double-layer capacitors (DLC). The energy management strategy is focused on reducing fuel consumption and minimizing the toxic exhaust emissions. In paper [16] the authors stated that the use of additional energy storage technologies is not enough to eliminate exhaust after-treatment systems from engines that are to comply with Stage III B standards. This is the result of testing the exhaust emissions of rail vehicle engines according to the ISO 8178. Which is done under specific engine load conditions, e.g. at the point of maximum load, in which additional circuits (electric or other) do not properly fulfill their task.

Ghaviha et al. [9] divided energy storage systems into stationary systems (SESS - stationary) and systems inside railway vehicles (OESS - On-board). The authors also point to the use of currently ultra-capacitors, batteries and flywheels in rail vehicles in both SEES and OESS systems. 
The system that has been in use the longest is the flywheel (used in Japan since 1970) [9].

Research conducted by Rupp et al. [21] indicate the possibilities of using flywheels to reduce the energy consumption by 9 to $31 \%$ (depending on the traffic conditions of light rail vehicles).
Energy storage methods in means of transport have been presented in Fig. 2. Possibilities of using energy storage systems in the context of vehicle power, energy and discharging time were presented in Fig. 3.

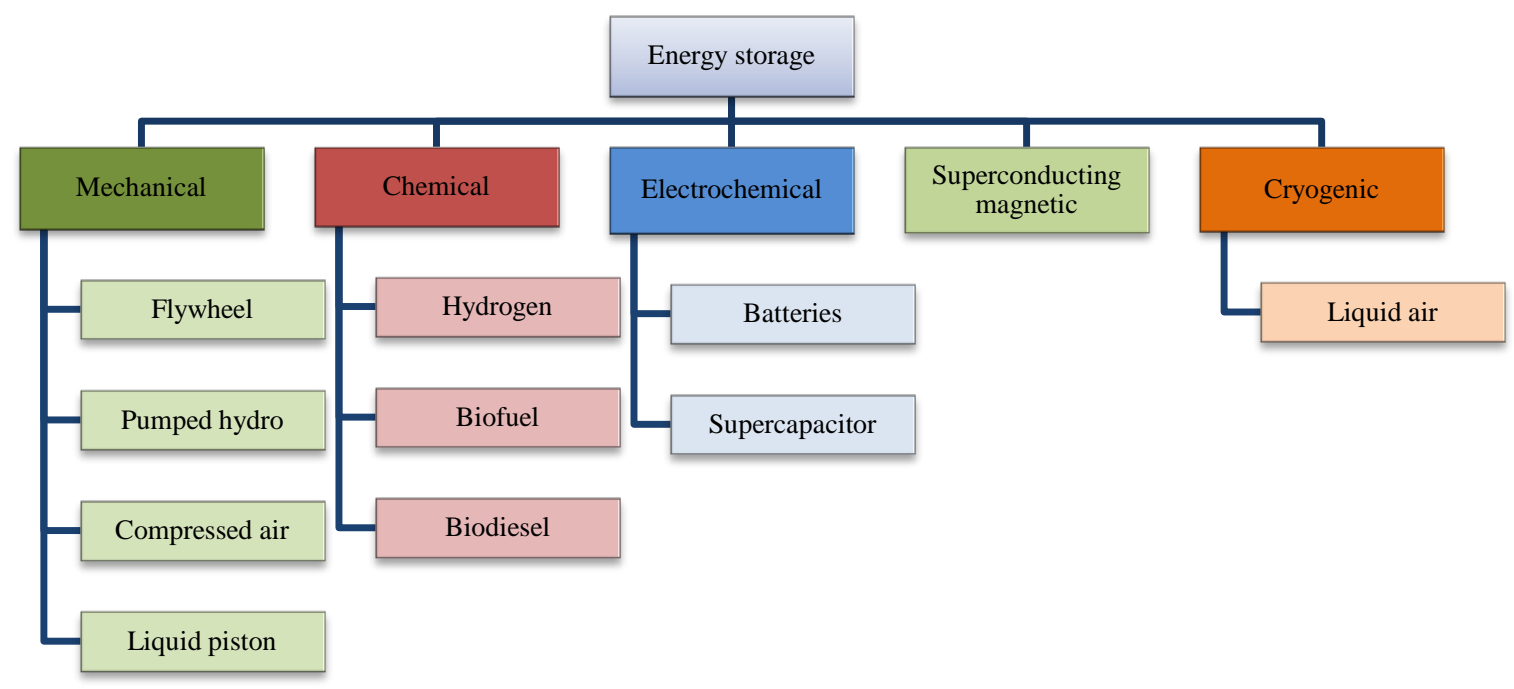

Fig. 2. Energy storage systems classification tree [2]

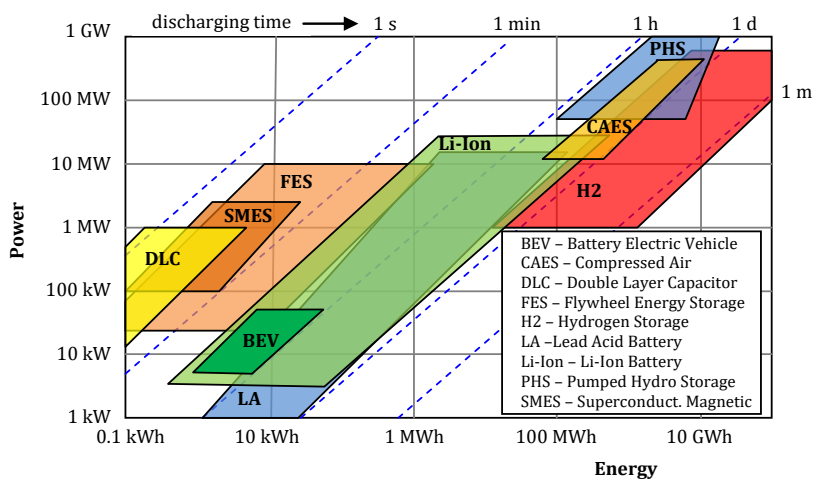

Fig. 3. Comparison of power, energy and discharging time of typical energy storage systems [10]

\section{Railway vehicle hybrid drive systems constructions}

\subsection{Introduction}

Hybrid drive systems used in rail vehicles may be equipped with:

a) hydrostatic systems (hydraulic),

b) flywheels,

c) lithium-ion batteries

and others.

Hydraulic drive systems include hydraulic motors/pumps whose power is greater than $4 \mathrm{~kW} / \mathrm{kg}$, and with efficiency of over $93 \%$. In addition, the power density of hydraulic accumulators is about 10 times greater than that of electrochemical batteries and is about $5 \mathrm{~kW} / \mathrm{kg}$. Unfortunately, the energy density is about 15 times lower with respect to Li-Ion batteries $-4-11 \mathrm{~kJ} / \mathrm{kg}$ [22].

Comparison of power and energy indicators for different batteries reveals the different parameters of these batter- ies. Electrochemical systems (both NiMH and Li-Ion batteries) have a much higher energy density than power densities (Fig. 4). Therefore, their use in rail vehicles significantly increases the vehicle range.

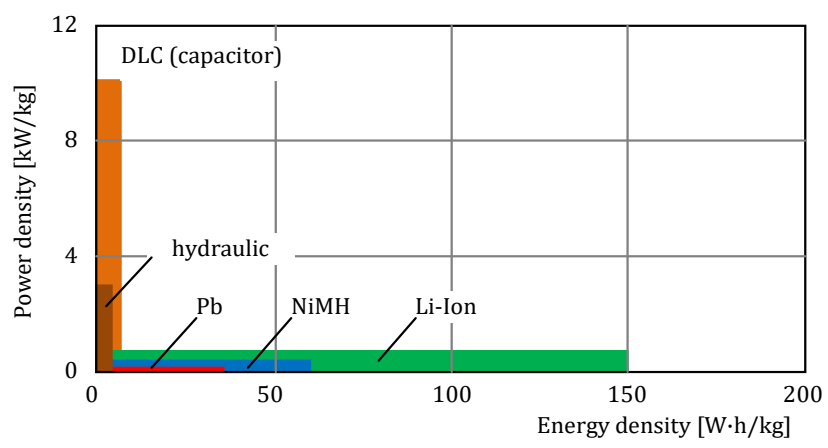

Fig. 4. Comparison of power and energy density of available batteries [11]

The use of hydraulic or ultra-capacitor systems does not provide similar energy density values. However, the high power density of the ultracapacitors allows them to be used in heavy vehicles. High power density energy storage systems allow them to be quickly charged, and this results in them being more effective when used in conditions of frequent stops.

It is possible to categorize the following hybrid drive solutions (based on compression-ignition diesel engines):

a) hybrid parallel hydrostatic drive (hydraulic),

b) hybrid parallel drive with a flywheel (mechanical),

c) hybrid parallel drive with an ultra-capacitor system,

d) diesel-electric (battery) hybrid drive system,

e) diesel-electric (battery and ultracapacitors) hybrid drive system. 


\subsection{Hydrostatic systems}

Hybrid parallel hydrostatic drive (hydraulic) is presented in Fig. 5. The coupling (gear) is mounted between the electric motor (MG) and the main transmission. It is a system in which the combustion engine is connected in parallel with the hydraulic system.

A different construction is presented in Fig. 6. It also contains a parallel connection of the hydraulic drive with the internal combustion engine, the generator and the electric motor connected in series. In this solution, the combustion engine is used only to drive the current generator (reference $G$ in Fig. 5). In the mechanical transmission, the torque values are added up from the hydraulic system and from the electric motor system (MG).

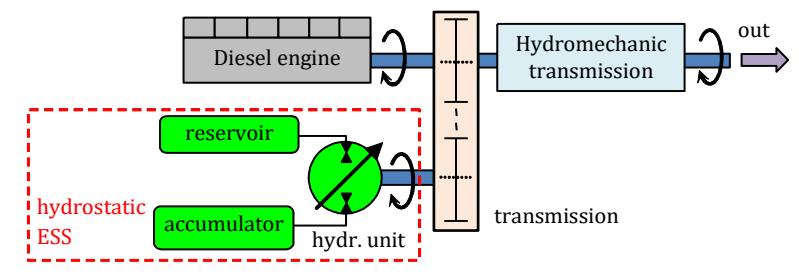

Fig. 5. A parallel hybrid drive of an internal combustion engine with a hydromechanical transmission and a hydrostatic system [17]

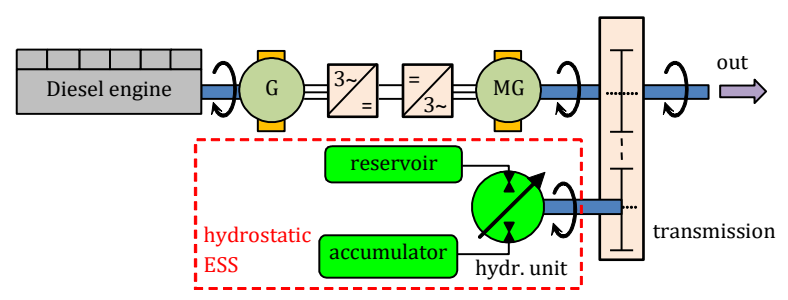

Fig. 6. A parallel hybrid drive of a hydrostatic system and a serial connection of a combustion engine with a generator and an electric motor [17]

The layout shown in Fig. 5 is currently implemented, among others by Bosch-Rexroth [4] and Plasser \& Theurer (Fig. 7).

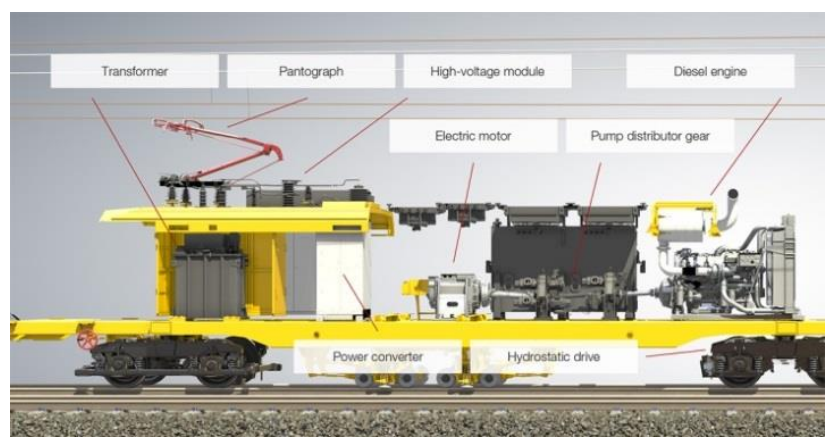

Fig. 7. The hybrid drive of a rail vehicle with a hydrostatic system (09-4X Dynamic Tamping Express E3 and the BDS 2000 E3 - Plasser \& Theurer) [25]

Hydraulic motors have not only higher efficiency than electric motors, but in addition - they generate similar torque values - they have much smaller dimensions (Fig. 8). Such conditions allow these systems to be used even in passenger cars as well as placing the hydraulic motors at the wheels of the vehicle (or on the wheels themselves).

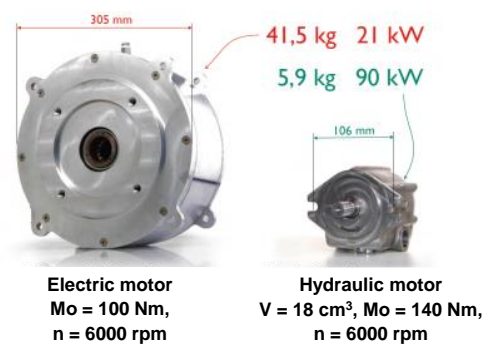

Fig. 8. Technical parameters comparison of electric and hydraulic motors [1]

\subsection{Hybrid systems with flywheels in rail vehicles}

Another solution for hybrid systems in rail vehicles is the use of flywheels (Fig. 9). The main parameters of flywheels used in rail vehicles include:

a) rotational speed in the range of 25,000-30,000 rpm,

b) the value of available energy from the range of $6 \mathrm{kWh}$ to $12 \mathrm{kWh}$, of which about $75 \%$ can be used (no work generated at low rotational speeds),

c) energy density of approximately $2 \mathrm{kWh} / \mathrm{m}^{3}$,

d) average charging and discharging time (flywheels are placed between ultracapacitors and electrochemical batteries),

e) efficiency of about $90 \%$.

An example of a solution for parallel hybrid drive with a combustion engine and flywheel is shown in Fig. 9. The flywheel in this solution serves as the drive system of the current generator in a serial connection with an electric motor. In such a system, recovery of flywheel energy requires two-way operation of both electrical machines (MG - Fig. 9).

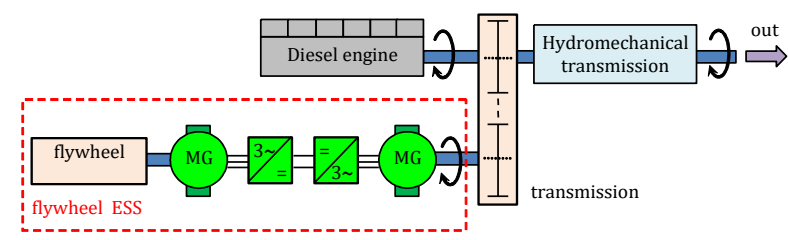

Fig. 9. A parallel hybrid drive with an internal combustion engine and a flywheel connected in series with a generator and an electric motor [17]

The use of an internal combustion engine in a hybrid drive as a current generator and flywheel also for electric current production is shown in Fig. 10. It is a parallel connection of an internal combustion engine (operating in a drive system with a power generator and electric motor connected in series) and a flywheel connected to a power generator. The output drive for the wheels is generated only by an electric motor. The lack of a flywheel system would allow the system to be classified as a series hybrid drive system.

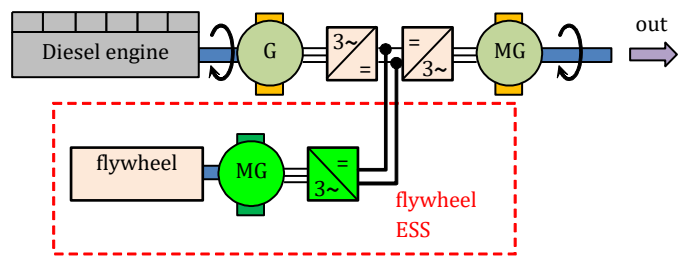

Fig. 10. Parallel hybrid drive with an internal combustion engine (DE) and a flywheel system working in series with an electric motor [17] 
An example of the application of this technology in rail vehicles is shown in Fig. 11. The flywheel presented is the result of a project in cooperation between Ricardo Artemis Intelligent Power and Bombardier. The project concerns the reduction of energy consumption by about $10 \%$ using highspeed flywheels as sources of kinetic energy storage.

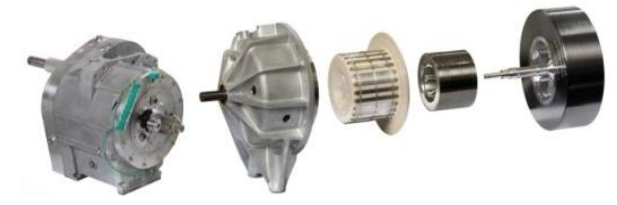

$$
\begin{aligned}
& E=4,5 \mathrm{MJ} \\
& D=360 \mathrm{~mm} \\
& \mathrm{~L}=160 \mathrm{~mm} \\
& \mathrm{~m}=22 \mathrm{~kg} \\
& \mathrm{n}=45000 \mathrm{obr} / \mathrm{min}
\end{aligned}
$$

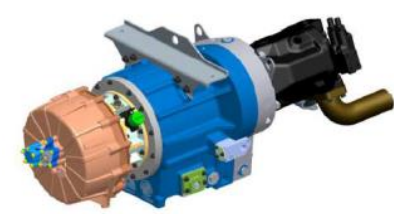

Fig. 11. The flywheel and its components with $220 \mathrm{~kJ}$ TorqStor from Ricardo [6]

\subsection{Hybrid systems with electrochemical batteries}

Electrochemical energy sources are the most widespread energy storage systems. Their high energy density makes it possible to obtain a higher vehicle range than with the use of other energy storage systems: mechanical or hydraulic.

A typical parallel hybrid drive system of an internal combustion engine and an electrochemical battery is shown in Fig. 12. The use of AC motors requires constant voltage converters (from battery) to alternating voltage (higher efficiency values of such motors, especially in the low speed range). In such a system (so-called mild hybrid) one electric machine with reversible operation is used.

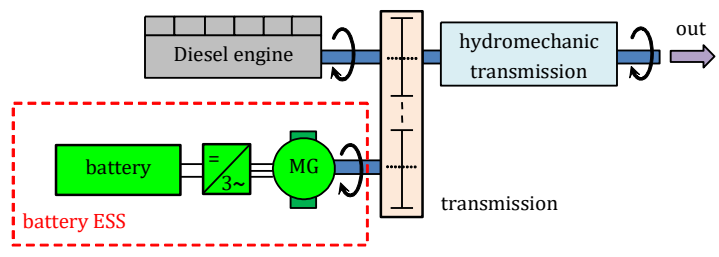

Fig. 12. A hybrid parallel drive of an internal combustion engine (DM) with a hydromechanical transmission, a battery system and an electric motor $[14,17]$

The use of an electrochemical battery instead of a flywheel (as in Fig. 10) results in a similar configuration of the parallel hybrid drive with the combination of an internal combustion engine (operated in series with an electric motor) with an electrochemical battery system (Fig. 13).

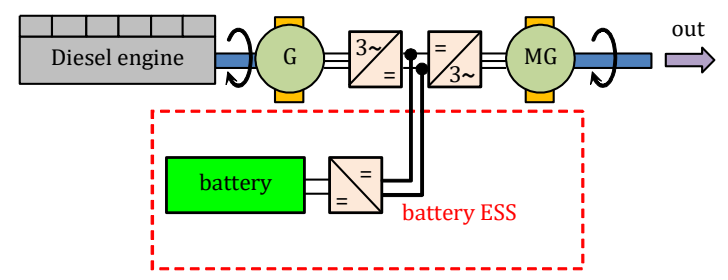

Fig. 13. A parallel hybrid drive of an internal combustion engine (DE) with a system of batteries operating in series with an electric motor in a drive system [17]
The use of electrochemical batteries allows using a configuration, which will provide a high value of power or high value of energy stored. High power density ensures a modular design, while high energy density - appropriate

\begin{tabular}{|c|c|c|}
\hline Description & High power density & High Energy density \\
\hline $\begin{array}{l}P=\eta(1-\eta) \frac{U^{2}}{R} \\
P=\frac{U^{2}}{4 R}\end{array}$ & & \\
\hline Model & MA2a & CH75-6 \\
\hline Configuration & 48 cells (series) & 6 cells (series) \\
\hline $\begin{array}{l}\text { Voltage/ } \\
\text { capacity }\end{array}$ & $173 \mathrm{~V} ; 5.5 \mathrm{Ah}$ & $22.2 \mathrm{~V} ; 75 \mathrm{Ah}$ \\
\hline Energy density & $46 \mathrm{Wh} / \mathrm{dm}^{3}(100 \%)$ & $102 \mathrm{Wh} / \mathrm{dm}^{3}(221 \%)$ \\
\hline Power density & $865 \mathrm{~W} / \mathrm{kg}(346 \%)$ & $250 \mathrm{~W} / \mathrm{kg}(100 \%)$ \\
\hline Applications & $\begin{array}{l}\text { - Compromise } \\
\text { between power and } \\
\text { capacity } \\
\text { - Fast charging } \\
\text { during regenerative } \\
\text { braking }\end{array}$ & $\begin{array}{l}\text { - High energy density } \\
\rightarrow \text { compact dimen- } \\
\text { sions } \\
\text { - A slight drop in } \\
\text { efficiency at lower } \\
\text { temperature }\end{array}$ \\
\hline
\end{tabular}
range of the rail vehicle. Examples of such Hitachi battery solutions are shown in Table 1.

Table. 1. Battery configurations in applications for hybrid drive of rail vehicles [18]

\section{Energy flow control strategies}

The diesel-electric hybrid drive is characterized by cyclic recharges and discharges of the battery. The nominal battery charge (SOC) is approximately $50 \%$ (Fig. 14). The use of Ni-MH batteries means that their charge/discharge level is not too high - it is in the range of $40-60 \%$. The use of Li-Ion batteries allows for much higher threshold values: up to $80 \%$ SOC when charging and down to about $20 \%$ when discharged. If the typical range for a battery is 25 $75 \%$ SOC, this means that the capacity of the battery used must be twice as large as the intended capacity. For this reason, the use of ultracapacitors may increase the usability of electrochemical energy storage sources.

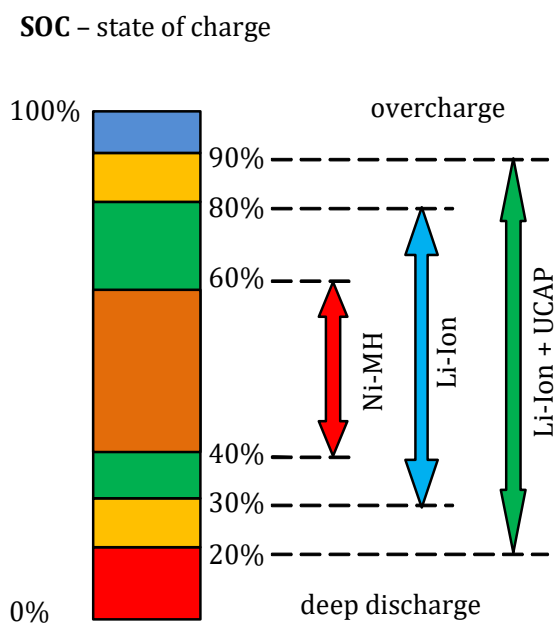

Fig. 14. Conditions for charging and discharging typical battery systems in hybrid drive systems [12,19] 
The specificity of rail vehicles operation and the hybrid drive systems used in them forces specific types of cooperation between the drive sources. An example of a typical rail vehicle operating speed curve is shown in Fig. 15a. It shows that the initial driving fragment is made using only the electric drive. In such conditions, the system discharges the batteries from the maximum level (about 60\%) - zone D (Fig. 15b). Achieving and maintaining a specific speed

a)

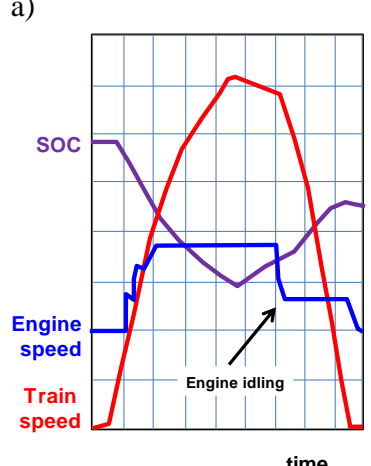

)

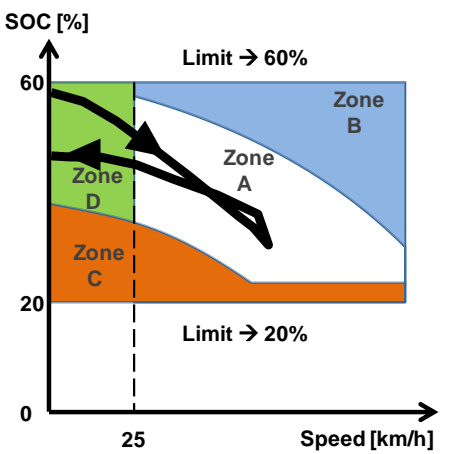

Power running:

Zone A:

Engine highest effic.

Zone B:

Engine idling

Fig. 15. Example of a hybrid drive system control: a) route, b) hybrid control zones, taking into account the battery charge level [8]

results in a constant rotational speed of the internal combustion engine and further discharge of the batteries (parallel drive). The internal combustion engine operating conditions correspond to its high efficiency. Due to the considerable kinetic energy of such a composition, it is possible to limit the power of the internal combustion engine and to let it idle (Fig. 15a - engine idling, zone A - Fig. 15b). The speed reduction is achieved using regenerative braking, which results in the recovery of the kinetic energy of the vehicle and increasing the level of charge of the batteries. Drive operation characteristics (line in Fig. 15b) moves from zone A to zone D.
Similar research is currently being conducted, and concerns the limitation of SOC changes applied to rail vehicles lithium-ion battery [23].

\section{Conclusions}

The use of hybrid drive systems in rail vehicles can result in a significant reduction of toxic exhaust emissions and a reduction in fuel consumption. Similarly to other vehicle categories, the use of this drive type allows pushing the engine operating points on the internal combustion engine characteristics towards higher overall efficiency. In the case of rail vehicles, the biggest benefit of using a hybrid drive is limiting the combustion unit idle operation time, where the share of idling for shunting rail vehicles ranges from 50 to $70 \%[3,13]$. By eliminating the idling operation of the combustion engine, significant economic benefits are obtained. Kałuża [13] assessed that in the case of the SM31 locomotive, the daily reduction of diesel oil consumption, resulting only from the limitation of the time the internal combustion engine spend idling and without load, may amount to approx. $160-168 \mathrm{dm}^{3}$.

As it was mentioned in this paper, the type of hybrid drive, and along with it the energy storage technology it uses, should be selected on an individual basis depending on the purpose and nature of the work performed by the rail vehicle. At the stage of selecting the aforementioned solutions, it is important to assess the drive energy demand. With long-term demand for electricity, the best solution should be choosing electrochemical batteries, which are also available in different configurations, focused on higher power density or higher energy density. In that case, the engine more often work in the field of highest efficiency, even during battery charging. That way help to improve the range of the vehicle. In turn, frequent stops and starts (such as in shunting work) makes high power, fast charging and discharging the more favorable features for a drive system, thus ultra-capacitors and flywheels become the better solution to use.

\section{Nomenclature}

$\begin{array}{ll}\text { DLC } & \text { double-layer capacitor } \\ \text { ESS } & \text { energy storage system } \\ \text { G } & \text { generator } \\ \text { Li-Ion } & \text { lithium-ion battery } \\ \text { MG } & \text { motor/generator } \\ \text { Mo } & \text { torque } \\ n & \text { engine/motor speed }\end{array}$

Ni-MH nickel metal hydride battery

OESS on-board energy storage system

$\mathrm{Pb} \quad$ lead-acid battery

SESS stationary energy storage system

SOC state of charge

UCAP ultracapacitor

V volume

\section{Bibliography}

[1] ACHTEN, P. The Hydrid a hydraulic hybrid transmission. Seminar für Fahrzeugtechnik - Institut für Fahrzeugtechnik und Mobile Arbeitsmaschinen, 12 November 2009.

[2] ANEKE, M., WANG, M. Energy storage technologies and real life applications - A state of the art review. Applied Energy. 2016, 179, 350-377. DOI: 10.1016/j.apenergy.2016. 06.097
[3] BABEŁ, M. Zwiększenie efektywności pracy lokomotyw spalinowych SM31 w eksploatacji. Technika Transportu Szynowego. 2012, 1-2, 41-44.

[4] BASELEY, S., EHRET, C., GREIF, E., KLIFFKEN, M. Hydraulic hybrid systems for commercial vehicles. SAE Technical Paper. 2007, 2007-01-4150. DOI: 10.4271/2007$01-4150$ 
[5] COUSINEAU, R. Development of a hybrid switcher locomotive the Railpower Green Goat. IEEE Instrumentation \& Measurement Magazine. 2006, 9(1), 25-29. DOI: 10.1109/ MIM.2006.1634954

[6] DDFlyTrain flywheel hybrid technology to deliver around $10 \%$ fuel savings, rapid ROI. www.greencarcongress.com/ 2015/06/20150617-ddflytrain.html

[7] Directive 2004/26/EC of the European Parliament and of the Council of 21 April 2004 amending Directive 97/68/EC on the approximation of the laws of the Member States relating to measures against the emission of gaseous and particulate pollutants from internal combustion engines to be installed in non-road mobile machinery. data.europa.eu/eli/dir/ 2004/26/oj.

[8] FUJII, T., TERAYA, N., OSAWA, M. Development of an NE train. JR EAST Technical Review. 2004, 4, 62-70.

[9] GHAVIHA, N., CAMPILlO, J., BOHLIN, M., DAHLQUIST, E. Review of application of energy storage devices in railway transportation. Energy Procedia. 2017, 105, 4561-4568. DOI:10.1016/ j.egypro.2017.03.980

[10] GUNEY, M.S., TEPE, Y. Classification and assessment of energy storage systems. Renewable and Sustainable Energy Reviews. 2017, 75, 1187-1197, DOI: 10.1016/j.rser.2016.11. 102

[11] HORIBA, T., MAESHIMA, T., MATSUMURA, T. et al. Applications of high power density lithium ion batteries. Journal of Power Sources. 2005, 146(1-2), 107-110. DOI:10.1016/j.jpowsour.2005.03.205

[12] Hybrid Locomotive, SustRail, Grant Agreement n: 265740 FP7.

[13] KAŁUŻA, A. Lokomotywa manewrowa sześcioosiowa SM31. Przetwarzanie danych z dwóch obserwowanych rejonów pracy. Warianty modernizacji źródeł energii układu napędowego. Logistyka. 2014, 6, 5124-5137.

[14] KINI, G. Energy management systems, 2011, InTech. www.intechopen.com/books/energy-management-systems/ management-of-locomotive-tractiveenergy-resources

[15] MAYET, C., POUGET, J., BOUSCAYROL, A., LHOM$\mathrm{ME}, \mathrm{W}$. Influence of an energy storage system on the energy consumption of a diesel-electric locomotive. IEEE Transactions on Vehicular Technology. 2014, 63(3), 1032-1040. DOI: 10.1109/TVT.2013.2284634

Maciej Andrzejewski, DEng. - Łukasiewicz Research Network - Rail Vehicles Institute "TABOR" in Poznan.

e-mail:m.andrzejewski@tabor.com.pl

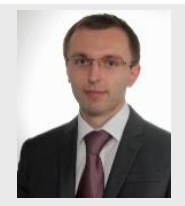

Prof. Ireneusz Pielecha, DSc., DEng. - Faculty of Transport Engineering, Poznan University of Technology.

e-mail: ireneusz.pielecha@put.poznan.pl
[16] MEINERT, M., MELZER, M., KAMBUROW, C. et al. Benefits of hybridisation of diesel driven rail vehicles: Energy management strategies and life-cycle costs appraisal. Applied Energy. 2015, 157, 897-904. DOI: 10.1016/ j.apenergy.2015.05.051

[17] MEINERT, M., PRENLELOUP, P., SCHMID, S., PALACIN, R. Energy storage technologies and hybrid architectures for specific diesel-driven rail duty cycles: Design and system integration aspects. Applied Energy. 2015, 157, 619629. DOI: 10.1016/j.apenergy.2015.05.015

[18] NAGAURA Y., OISHI R., SHIMADA M., KANEKO T. Battery-powered Drive Systems: Latest Technologies and Outlook. Hitachi Review. 2017, 66(2), 138-144.

[19] NELSON, R.F. Power requirements for batteries in hybrid electric vehicles. Journal of Power Sources. 2000, 91(1), 226. DOI: $10.1016 / \mathrm{S} 0378-7753(00) 00483-3$

[20] Regulation (EU) 2016/1628 of the European Parliament and of the Council of 14 September 2016 on requirements relating to gaseous and particulate pollutant emission limits and type-approval for internal combustion engines for non-road mobile machinery, amending Regulations (EU) No 1024/2012 and (EU) No 167/2013, and amending and repealing Directive 97/68/EC. http://data.europa.eu/eli/reg/ 2016/1628/oj

[21] RUPP, A., BAIER, H., MERTINY, P., SECANELL M. Analysis of a flywheel energy storage system for light rail transit, Energy. 2016, 107, 625-638. DOI: 10.1016/j.energy. 2016.04.051

[22] RYDBERG, K.-E. Energy efficient hydraulic hybrid drives. The $11^{\text {th }}$ Scandinavian International Conference on Fluid Power - SICFP'09, June 2-4, 2009, Linköping, Sweden.

[23] TAKAKUSAKI, A., SONODA, H., KOUNO, Y. Development of the optimal charge and discharge control method for diesel hybrid trains under high operational load. JR EAST Technical Review. 2017, 37, 55-60.

[24] The IEA-UIC Railway handbook on energy consumption \& $\mathrm{CO}_{2}$ emissions 2016 Edition, www.uic.org/IMG/pdf/ieauic_railway_handbook_2016.pdf

[25] The next step - the hybrid machine. Environmental protection \& sustainability, https://www.plassertheurer.com

Prof. Jerzy Merkisz, DSc., DEng. - Faculty of Transport Engineering, Poznan University of Technology. e-mail: jerzy.merkisz@put.poznan.pl

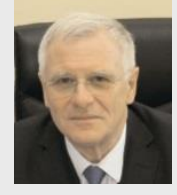

Mateusz Nowak, DEng. - Łukasiewicz Research Network - Rail Vehicles Institute "TABOR" in Poznan.

e-mail:m.nowak@tabor.com.pl

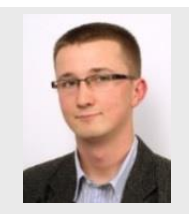

Robert Świechowicz, MSc. - Faculty of Transport Engineering, Poznan University of Technology. e-mail: robswiech@wp.pl 